\title{
The effect of temperature fluctuations on the cytoskeletal organisation and chromosomal constitution of the human oocyte
}

\author{
Paula A. Almeida and Virginia N. Bolton \\ Assisted Conception Unit, King's College School of Medicine and Dentistry, London, UK \\ Date submitted: 12.9 .95 . Date accepted: 12.10 .95 .
}

\section{Summary}

The effect of temperature fluctuation on spindle integrity and chromosomal organisation in the human oocyte, and the consequences of such effects on the chromosomal constitution of resulting parthenotes, were investigated. A total of 340 oocytes were stained immunocytochemically with an antibody to $a$-tubulin, and 502 were activated parthenogenetically. Exposure of oocytes to room temperature for 2, 10 or 30 min caused disruption of the spindle in $77 \%(n=26), 72 \%(n=18)$ and $89 \%(n=19)$ of cases respectively, with evidence of chromosomal dispersal in $50 \%, 56 \%$ and $52.6 \%$ respectively. These effects were reversed when oocytes were returned to $37^{\circ} \mathrm{C}$ after exposure to room temperature for $2 \mathrm{~min}$, but not after $10 \mathrm{~min}$ or $30 \mathrm{~min}$. Temperature reduction affected rates of parthenogenetic activation of oocytes ( $2 \mathrm{~min}: 67 \%, n=27 ; 10 \mathrm{~min}: 68 \%, n=28 ; 30 \mathrm{~min}: 54 \%, n=35$ ) and cleavage of resulting parthenotes, but only if oocytes were exposed to room temperature for $30 \mathrm{~min}(30 \mathrm{~min}: 53 \%, n=19)$. There is a direct association between temperature-induced spindle damage in the oocyte $(70 \%, 50$ of 63$)$ and chromosomal abnormalities in parthenotes developed from oocytes exposed to room temperature $(56 \%, 23$ of $41 ; p<0.01)$.

Key words: Chromosomal abnormalities, Cytoskeleton, Human, IVF, Oocyte, Spindle, Temperature changes

\section{Introduction}

In the mouse oocyte, cooling from $37^{\circ} \mathrm{C}$ to $25^{\circ} \mathrm{C}, 18^{\circ} \mathrm{C}$ or $4^{\circ} \mathrm{C}$ results in disruption of the microtubules of the meiotic spindle (Pickering \& Johñson, 1987). This disruption is reversed when the temperature is restored to $37^{\circ} \mathrm{C}$. In contrast, cooling of human oocytes to room temperature results in irreversible disruption to the spindle (Pickering et al., 1990), and it has been suggested that this may contribute to the high incidence of chromosomal abnormalities among human preimplantation embryos following in vitro fertilisation (IVF; Plachot et al., 1988; Ma et al., 1990; Pellestor et al., 1994).

The present study extends the earlier study of Pickering et al. (1990) by investigating the effects of

All correspondence to: V.N. Bolton, Assisted Conception Unit, Department of Obstetrics and Gynaecology, King's College School of Medicine and Dentistry, Denmark Hill, London SE5 8RX, UK. Telephone: + 44 (0171)-346 3158. Fax: +44 (0171)-274 3242. e-mail: RCJB190@BAY.CC.KCL.AC.UK. temperature fluctuation on microtubule organisation and chromosomal integrity in the human oocyte. In addition, the consequences of such effects on the chromosomal constitution of any resulting embryos are investigated, by cytogenetic analysis of parthenotes developed from oocytes that had been exposed to a temporary reduction in temperature.

\section{Materials and methods}

\section{Ethics of experimentation}

This investigation was approved by the Ethics Committee of King's College Hospital and licensed by the Human Fertilisation and Embryology Authority (UK). Provided appropriate consents had been obtained, oocytes were obtained from patients undergoing therapeutic in vitro fertilisation for the treatment of male factor infertility. 


\section{Source of oocytes}

Ovarian stimulation, ultrasound-directed follicle aspiration and IVF were performed as described previously (Bolton et al., 1989; Waterstone \& Parsons, 1992), except that the culture medium (Earle's balanced salt solution; EBS) was supplemented with $10 \%$ (v/v) Albuminar (Armour Pharmaceuticals), or with $0.001 \%$ (v/v) Synthetic Serum Replacement (SSR; Imperial Laboratories) and $1 \%(\mathrm{v} / \mathrm{v})$ human serum albumin. Oocytes which had failed to develop two pronuclei by $18-20 \mathrm{~h}$ post-insemination (hpi) were placed in $50 \mu \mathrm{l}$ drops of culture medium overlaid with light paraffin oil (Sigma) and taken for this study, providing no sibling oocytes had become fertilised.

\section{Cooling of oocytes}

Dishes containing oocytes were moved from $37^{\circ} \mathrm{C}$ to room temperature $\left(\mathrm{RT} ; 23^{\circ} \mathrm{C}\right.$ ) for 2,10 or $30 \mathrm{~min}$ and then (i) fixed immediately for immunocytochemistry; (ii) taken for parthenogenetic activation; or (iii) incubated at $37^{\circ} \mathrm{C}$ for $1 \mathrm{~h}$ or $4 \mathrm{~h}$ before fixation or parthenogenetic activation. Control oocytes were maintained at $37^{\circ} \mathrm{C}$ throughout. Oocytes from the same cohort were distributed randomly to the control and one or more of the experimental groups, with a minimum of two oocytes per group.

\section{Immunocytochemistry}

Oocytes were fixed for $30 \mathrm{~min}$ in HPEM buffer (Maro et al., 1985) at RT, washed in phosphate-buffered saline (PBS; Sigma), and stored at $4^{\circ} \mathrm{C}$ in PBS containing $1 \%$ $(\mathrm{v} / \mathrm{v})$ sodium azide (PBS-azide) for up to 1 week before processing for immunocytochemistry using the following series of incubations:

1. $10 \mathrm{~min}$ in PBS containing $1 \%(\mathrm{v} / \mathrm{v})$ goat serum (Sigma) at RT.

2. $45 \mathrm{~min}$ in PBS containing anti- $a$-tubulin monoclonal antibody $\left(1: 120\right.$; Sigma) at $37^{\circ} \mathrm{C}$.

3. $10 \mathrm{~min}$ in PBS containing $1 \%(\mathrm{v} / \mathrm{v})$ Tween (Sigma) at RT.

4. 3 rinses of 15 min each in PBS at RT.

5. $45 \mathrm{~min}$ in PBS containing $2 \%(\mathrm{v} / \mathrm{v})$ rhodaminelabelled anti-mouse IgG antibody and $20 \%(\mathrm{v} / \mathrm{v})$ human serum at $37^{\circ} \mathrm{C}$.

6. $10 \mathrm{~min}$ in PBS containing $1 \%(\mathrm{v} / \mathrm{v})$ Tween at RT.

7. 3 rinses of 15 min each in PBS at RT.

8. $20 \mathrm{~min}$ in PBS containing Hoechst dye 33258 ( $5 \mathrm{mg} / \mathrm{ml}$; Sigma) at RT.

9. $10 \mathrm{~min}$ in PBS at RT.

Oocytes were then mounted in Citifluor (City University), coverslips were sealed with clear nail varnish, and the slides stored at $-20^{\circ} \mathrm{C}$ for up to 3 days. Fluorescence was visualised using a confocal micro- scope with an excitation filter DM580 for rhodaminelabelled reagent, and a Nikon Diaphot inverted microscope under UV excitation (DM400) for Hoechst dye.

\section{Parthenogenetic activation}

Oocytes were incubated at $37^{\circ} \mathrm{C}$ for 5-7 $\mathrm{h}$ in EBS containing puromycin $(10 \mu \mathrm{g} / \mathrm{ml}$; Sigma $)$, after which they were rinsed in puromycin-free EBS at $37^{\circ} \mathrm{C}$ and incubated at $37^{\circ} \mathrm{C}$ for a further $18-20 \mathrm{~h}$. Those oocytes that developed pronuclei were cultured for a further $24 \mathrm{~h}$ before they were transferred to EBS containing $1 \mu \mathrm{g} / \mathrm{ml}$ colcemid (Gibco) and incubated for $24 \mathrm{~h}$ at $37^{\circ} \mathrm{C}$ before processing for cytogenetic analysis as described previously (Almeida \& Bolton, 1993).

\section{Statistical analysis}

Statistical analysis was carried out using the chisquared test, with the $p$ value set at $\leq 0.05$.

\section{Results}

A total of 842 oocytes were retrieved from 76 women (median age 32 years; range 25-39 years), all of which failed to fertilise following insemination in vitro with dysfunctional spermatozoa. The median number of oocytes retrieved per patient was 11 (range 7-22). Of the 842 oocytes, 340 (median 10 per patient; range 7-19) were taken for immunocytochemical staining (controls, 158; experimental, 182), and 502 (median 12 per patient; range 8-22) were exposed to puromycin for parthenogenetic activation (controls, 242; experimental, 260).

Exposure to RT for $2 \mathrm{~min}, 10 \mathrm{~min}$ and $30 \mathrm{~min}$ resulted in a reduction in temperature of the culture drops from $37^{\circ} \mathrm{C}$ to $32^{\circ} \mathrm{C}, 27^{\circ} \mathrm{C}$ and $25^{\circ} \mathrm{C}$, respectively. The nature of the effects of these reductions in temperature on the spindle and chromatin of oocytes is illustrated in Fig. 1. The incidence of each effect among control oocytes and those exposed to temperature reduction for different lengths of time with or without further incubation at $37^{\circ} \mathrm{C}$ is shown in Table 1 , and the overall incidence of spindle abnormalities and chromatin dispersal are illustrated in Figs. 2 and 3 respectively.

\section{Effect of temperature reduction on the meiotic spindle}

The incidence of spindle abnormality is significantly greater in oocytes exposed to RT and analysed immediately than in controls, whether oocytes were cooled for $2 \mathrm{~min}, 10 \mathrm{~min}$ or $30 \mathrm{~min}$ (Fig. $2 a$ ). There is no significant difference in the incidence of spindle abnormality between oocytes exposed to RT for different lengths of time. 
When oocytes were returned to $37^{\circ} \mathrm{C}$ for either $1 \mathrm{~h}$ or $4 \mathrm{~h}$ after exposure to RT for only $2 \mathrm{~min}$, normal spindle structure was restored; the incidence of spindle abnormalities in these experimental groups is not significantly different from controls (Fig. $2 b$ and $c$, respectively). In contrast, where oocytes were exposed to RT for $10 \mathrm{~min}$ or $30 \mathrm{~min}$, the incidence of spindle abnormalities remained significantly different from controls, whether they were returned to $37^{\circ} \mathrm{C}$ for $1 \mathrm{~h}$ (Fig. $2 b$ ) or $4 \mathrm{~h}$ (Fig. $2 c$ ).

There is no significant difference in the rate of spindle abnormality among any of the control groups.

\section{Effect of temperature reduction on chromosomal dispersal}

The incidence of chromosomal dispersal is significantly greater in oocytes exposed to RT and analysed immediately than in controls, whether oocytes were cooled for $2 \mathrm{~min}, 10 \mathrm{~min}$ or $30 \mathrm{~min}$ (Fig. $3 a$ ). There is no significant difference in the incidence of chromosomal dispersal between oocytes exposed to RT for different lengths of time.

The incidence of oocytes with dispersed chromosomes is not significantly different in oocytes that were cooled for $2 \mathrm{~min}$ and then returned to $37^{\circ} \mathrm{C}$ for either $1 \mathrm{~h}$ (Fig. $3 b$ ) of $4 \mathrm{~h}$ (Fig. 3c) compared with controls. In contrast, where oocytes were exposed to RT for $10 \mathrm{~min}$ or $30 \mathrm{~min}$ and then returned to $37^{\circ} \mathrm{C}$, the incidence of chromosomal dispersal remained significantly different from controls, whether they were returned to $37^{\circ} \mathrm{C}$ for $1 \mathrm{~h}$ (Fig. $3 b$ ) or $4 \mathrm{~h}$ (Fig. 3c).

There is no significant difference in the rate of chromosomal dispersal among any of the control groups.

Among all the experimental groups, a total of 20 oocytes displayed both spindle abnormalities and dispersed chromosomes, compared with 29 displaying an

Table 1 The effects of temperature changes on the cytoskeletal organisation and chromatin of human oocytes

\begin{tabular}{|c|c|c|c|c|c|c|c|c|}
\hline \multirow[b]{3}{*}{ Experimental group } & \multicolumn{8}{|c|}{ No. of oocytes } \\
\hline & \multirow[b]{2}{*}{ Total } & \multicolumn{5}{|c|}{ Spindle morphology } & \multicolumn{2}{|l|}{ Chromatin } \\
\hline & & Normal & Disrupted & None & Astral & Reduced & Compact & Dispersed \\
\hline \multicolumn{9}{|l|}{$2 \mathrm{~min} \mathrm{RT}$} \\
\hline Experimental & 26 & 6 & 15 & 4 & 1 & 0 & 13 & 13 \\
\hline Control & 27 & 16 & 7 & 2 & 2 & $\mathbf{0}$ & 22 & 5 \\
\hline \multicolumn{9}{|c|}{$2 \min \mathrm{RT}+1 \mathrm{~h}$ at $37^{\circ} \mathrm{C}$} \\
\hline Experimental & 19 & 11 & 6 & 1 & 1 & 0 & 18 & 1 \\
\hline Control & 18 & 12 & 4 & 0 & 2 & 0 & 16 & 2 \\
\hline \multicolumn{9}{|c|}{$2 \min \mathrm{RT}+4 \mathrm{~h}$ at $37^{\circ} \mathrm{C}$} \\
\hline Experimental & 17 & 11 & 5 & 0 & 1 & 0 & 15 & 2 \\
\hline Control & 16 & 13 & 1 & 0 & 2 & 0 & 15 & 1 \\
\hline \multicolumn{9}{|l|}{$10 \mathrm{~min}$ RT } \\
\hline Experimental & 18 & 5 & 10 & 1 & 0 & 2 & 8 & 10 \\
\hline Control & 14 & 10 & 4 & 0 & 0 & 0 & 12 & 2 \\
\hline \multicolumn{9}{|c|}{$10 \mathrm{~min} \mathrm{RT}+1 \mathrm{~h}$ at $37^{\circ} \mathrm{C}$} \\
\hline Experimental & 21 & 4 & 15 & 2 & 0 & 0 & 10 & 11 \\
\hline Control & 16 & 12 & 4 & 0 & 0 & 0 & 14 & 2 \\
\hline \multicolumn{9}{|c|}{$10 \mathrm{~min} \mathrm{RT}+4 \mathrm{~h}$ at $37^{\circ} \mathrm{C}$} \\
\hline Experimental & 19 & 5 & 9 & 4 & 1 & 0 & 10 & 9 \\
\hline Control & 17 & 11 & 6 & 0 & 0 & 0 & 15 & 2 \\
\hline \multicolumn{9}{|l|}{$30 \mathrm{~min} \mathrm{RT}$} \\
\hline Experimental & 19 & 2 & 10 & 4 & 2 & 1 & 9 & 10 \\
\hline Control & 19 & 13 & 4 & 2 & 0 & 0 & 16 & 3 \\
\hline \multicolumn{9}{|c|}{$30 \mathrm{~min} \mathrm{RT}+1 \mathrm{~h}$ at $37^{\circ} \mathrm{C}$} \\
\hline Experimental & 25 & 6 & 15 & 3 & 1 & $\mathbf{0}$ & 13 & 12 \\
\hline Control & 16 & 10 & 5 & 1 & 0 & 0 & 14 & $\ddot{2}$ \\
\hline \multicolumn{9}{|c|}{$30 \mathrm{~min} \mathrm{RT}+4 \mathrm{~h}$ at $37^{\circ} \mathrm{C}$} \\
\hline Experimental & 18 & 5 & 13 & 0 & 0 & 0 & 8 & 10 \\
\hline Control & 15 & 12 & 2 & 1 & 0 & 0 & 13 & 2 \\
\hline
\end{tabular}

RT, room temperature. 

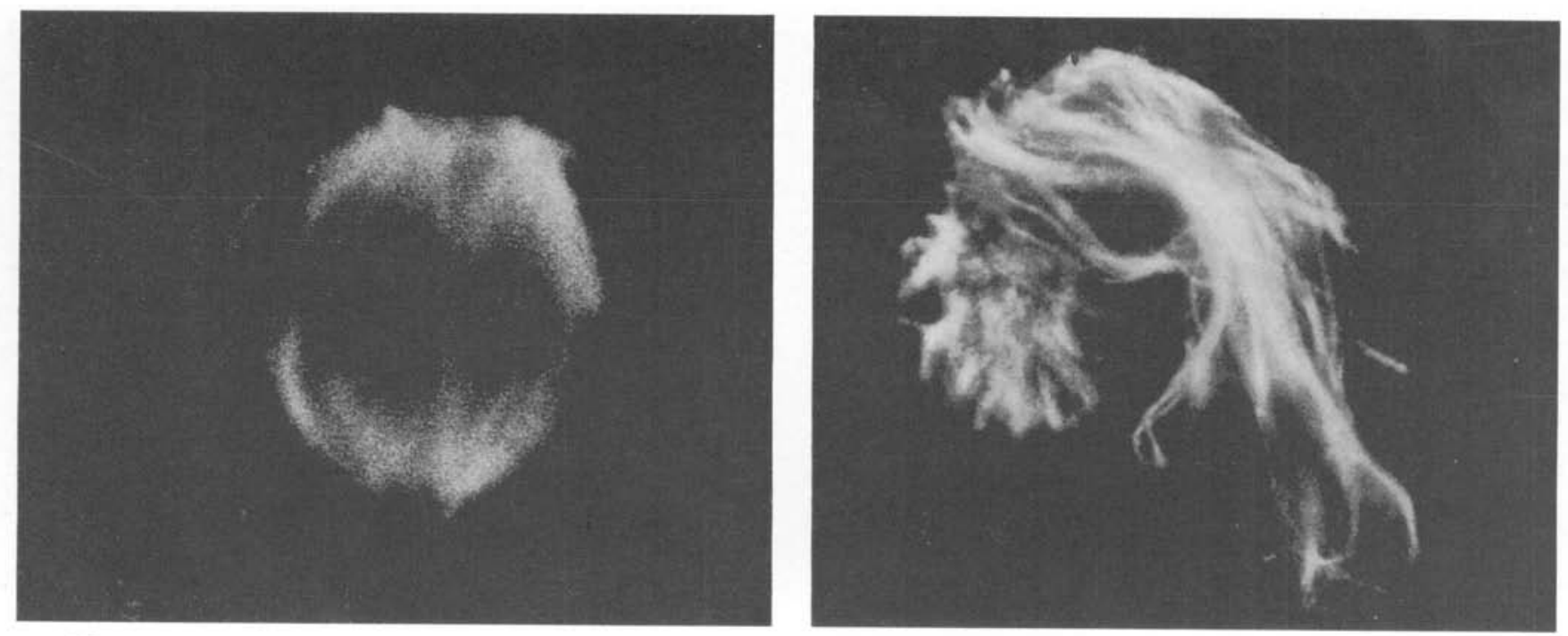

a

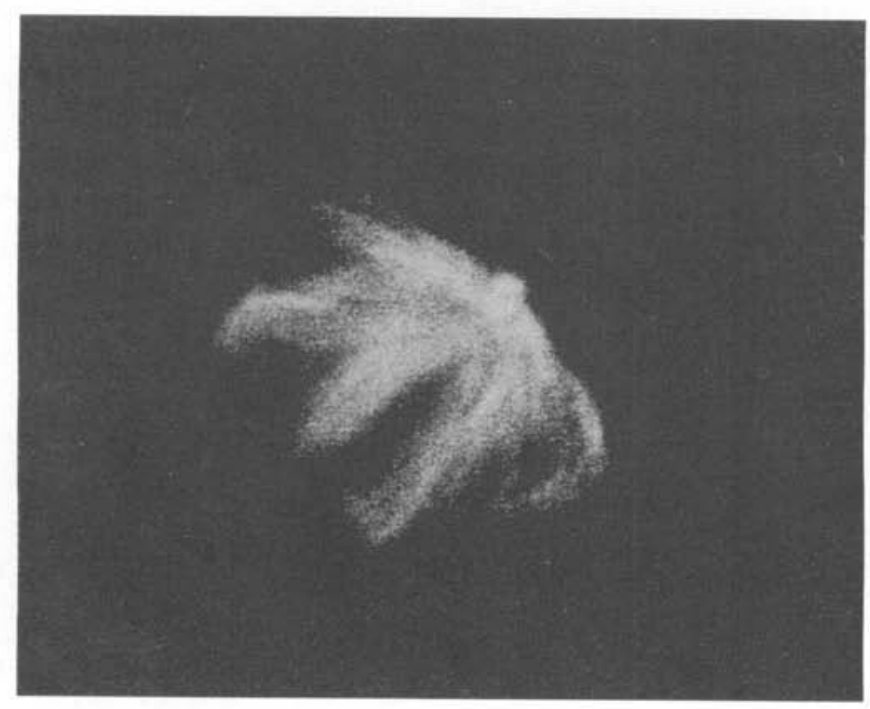

b
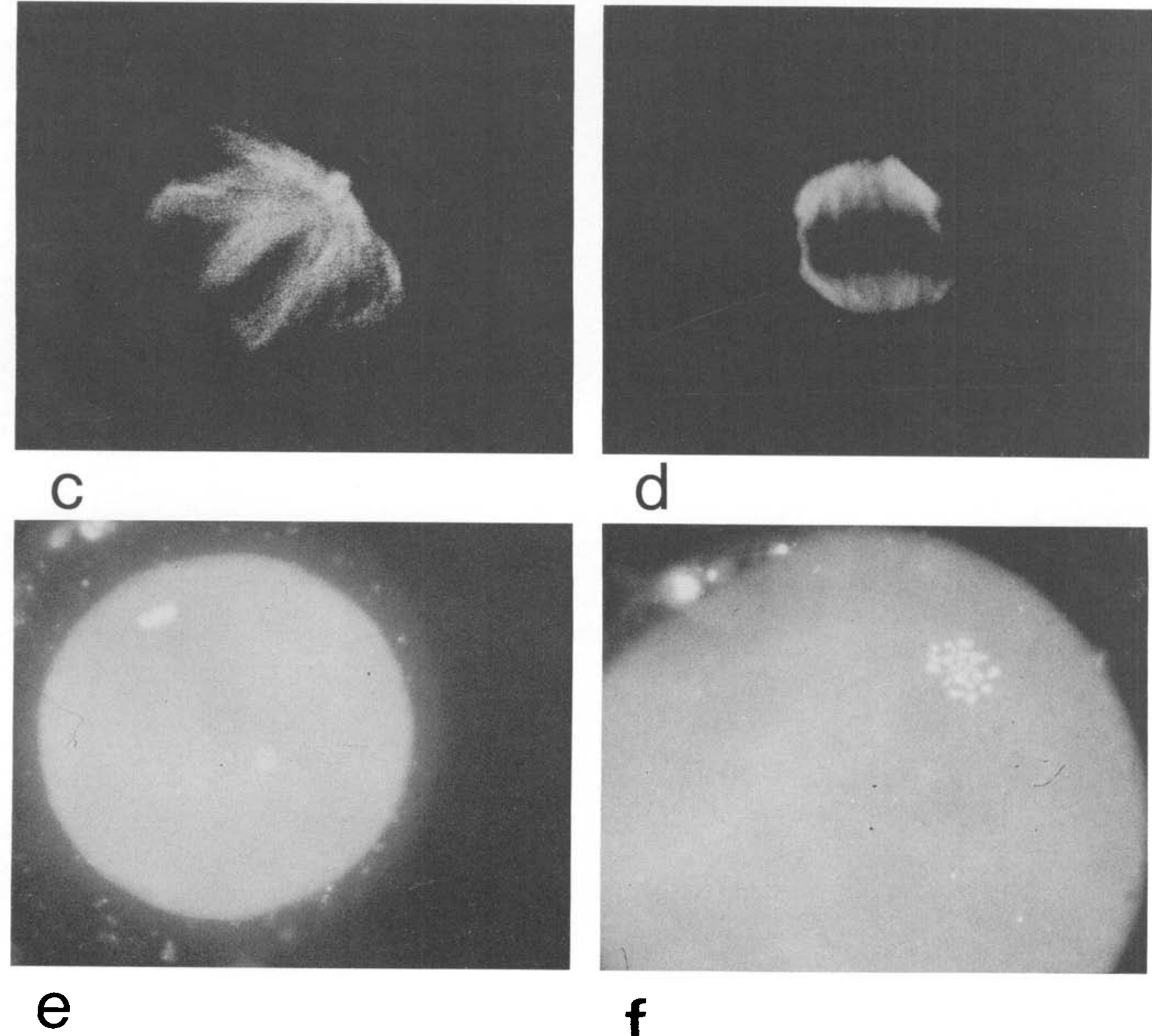

$f$

Figure 1 Oocytes stained immunocytochemically with anti-a-tubulin to visualise the spindle $(a, b, c, d)$ and with Hoechst dye 33258 to visualise chromatin $(e, f)$. (a) Normal spindle morphology; $(b)$ distupted spindle; $(c)$ astral spindle; $(d)$ reduced spindle; $(e)$ chromosomes aligned on the metaphase plate; $(f)$ dispersed chromosomes. 


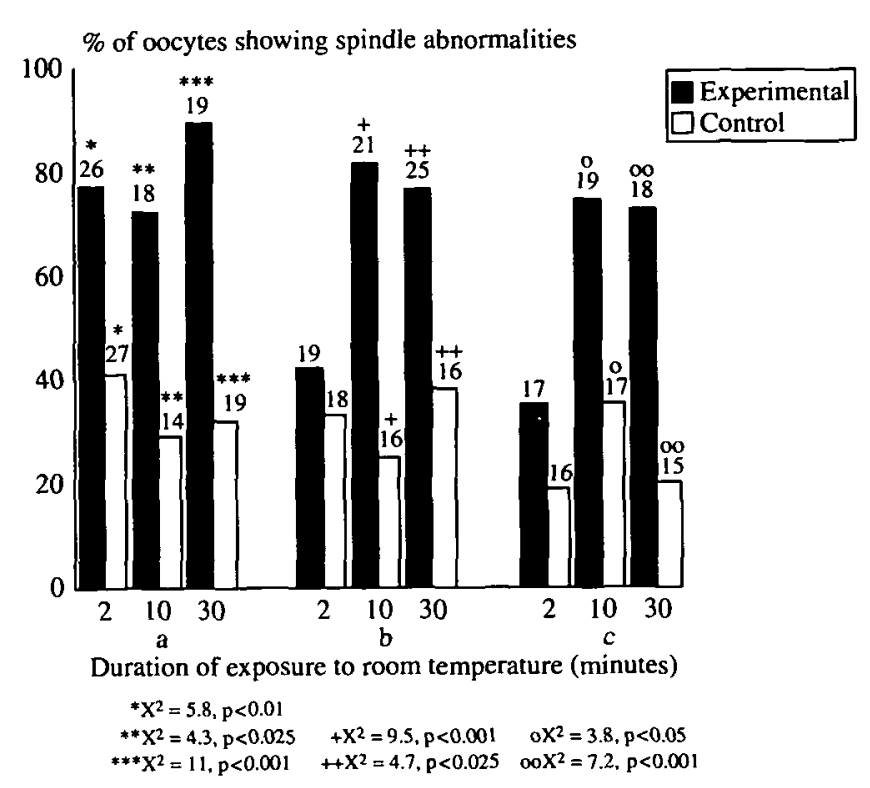

Figure 2 Histogram illustrating the incidence of spindle abnormalities following exposure to temperature reduction for 2, 10 or $30 \mathrm{~min}$ followed by (a) immediate analysis, or incubation at $37^{\circ} \mathrm{C}$ for (b) $1 \mathrm{~h}$ or $(c) 4 \mathrm{~h}$.

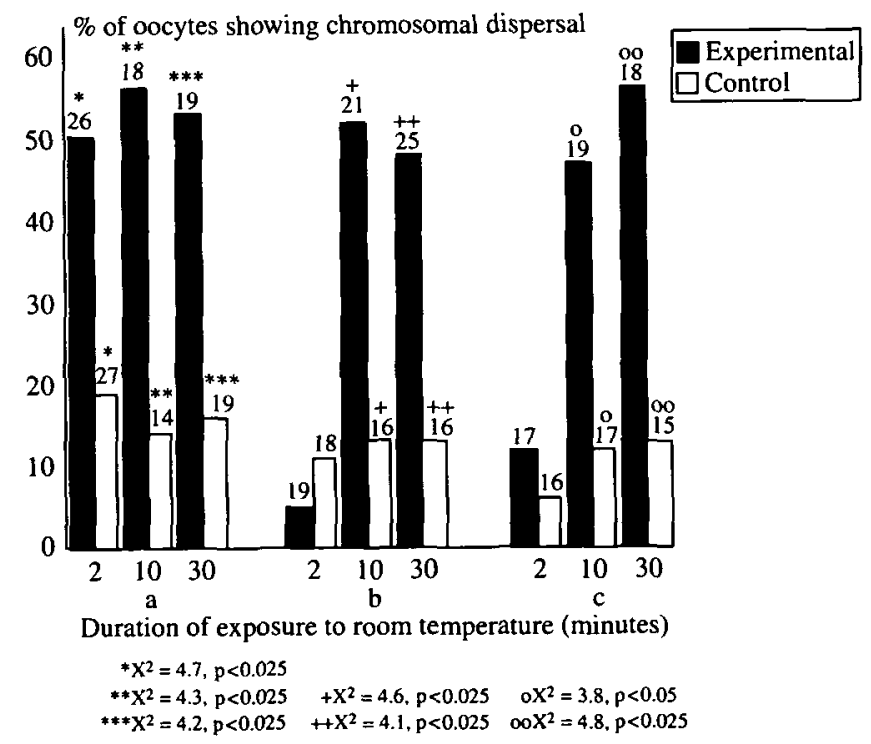

Figure 3 Histogram illustrating the incidence of chromatin dispersal following exposure to temperature reduction for 2 , 10 or 30 min followed by (a) immediate analysis, or incubation at $37^{\circ} \mathrm{C}$ for $(b) 1 \mathrm{~h}$ or $(c) 4 \mathrm{~h}$.

abnormal spindle but normal, compact chromosomes, 3 with a normal spindle and dispersed chromosomes, and 11 with a normal spindle and normal, compact chromosomes. Thus, there is no direct association between the incidence of spindle abnormalities and dispersal of chromosomes (NS; $\chi^{2}=1.01 ; p>0.25$ ).
Effect of temperature reduction rates of parthenogenetic activation and cleavage

The results of parthenogenetic activation and cytogenetic analysis following exposure to temperature reduction for each time interval are shown in Table 2 , and the overall incidence of activation, cleavage and chromosomal abnormality are illustrated in Figs. 4, 5 and 6 respectively.

Significantly fewer oocytes that were puromycintreated immediately after exposure to RT underwent activation than controls, whether oocytes were cooled for $2 \mathrm{~min}, 10 \mathrm{~min}$, or $30 \mathrm{~min}$ (Fig. $4 a$ ). There is no significant difference in the rate of activation between the groups exposed to RT for different lengths of time. However, when oocytes were returned to $37^{\circ} \mathrm{C}$, whether for $1 \mathrm{~h}$ (Fig. $4 \mathrm{~b}$ ) or $4 \mathrm{~h}$ (Fig. $4 \mathrm{c}$ ), after exposure to RT for only $2 \mathrm{~min}$, there is no significant difference in the rates of activation in the experimental groups compared with controls. In contrast, when oocytes were exposed to RT for $10 \mathrm{~min}$ or $30 \mathrm{~min}$, the incidence of activation remained significantly lower than controls, whether they were returned to $37^{\circ} \mathrm{C}$ for $1 \mathrm{~h}$ (Fig. $4 b$ ) or $4 \mathrm{~h}$ (Fig. $4 c$ ).

The number of activated oocytes that underwent cleavage is not significantly different between oocytes that had been exposed to RT for $2 \mathrm{~min}$ or $10 \mathrm{~min}$, whether they were treated with puromycin immediately (Fig. 5a), or after being returned to $37^{\circ} \mathrm{C}$ for

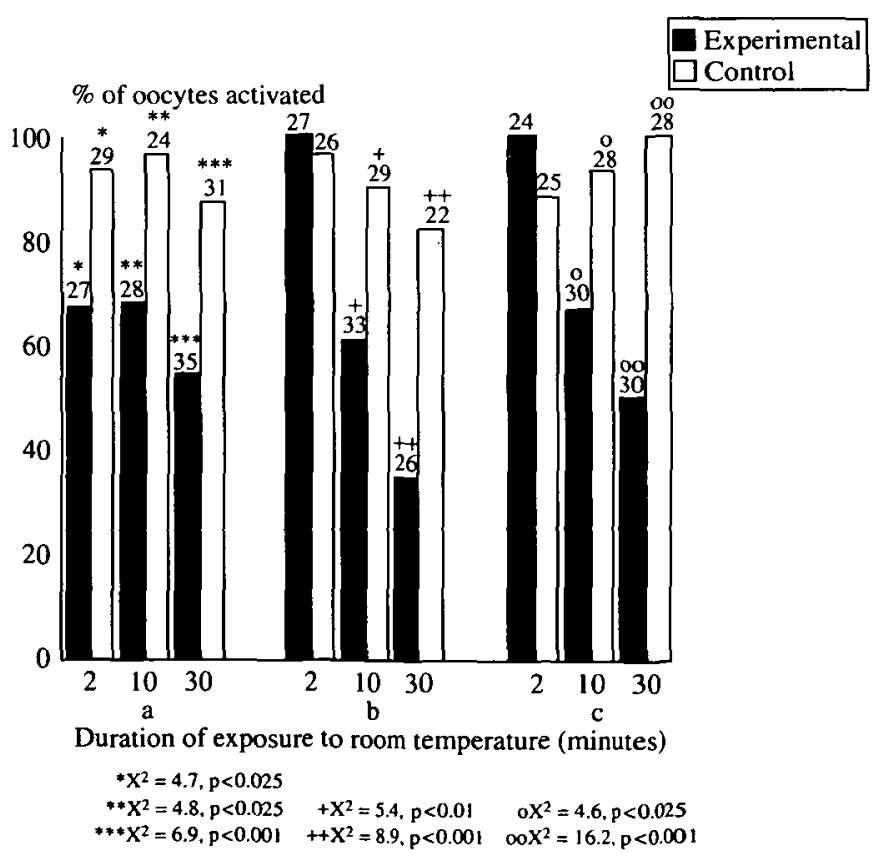

Figure 4 Histogram illustrating the incidence of oocyte activation following exposure to temperature reduction for 2,10 or $30 \mathrm{~min}$ followed by $(a)$ immediate analysis, or incubation at $37^{\circ} \mathrm{C}$ for $(b) 1 \mathrm{~h}$ or $(c) 4 \mathrm{~h}$. 
Table 2 Cytogenetic analysis of parthenotes derived from human oocytes exposed to temperature changes

\begin{tabular}{|c|c|c|c|c|c|c|c|c|c|}
\hline \multirow[b]{2}{*}{ Experimental group } & \multicolumn{2}{|c|}{ No. of oocytes } & \multicolumn{7}{|c|}{ No. of parthenotes } \\
\hline & Total & Activated & $\begin{array}{l}\text { Arrested at } \\
\text { the 1-cell } \\
\text { stage }\end{array}$ & $\begin{array}{l}\text { Abnormal } \\
\text { karyotype }\end{array}$ & $\begin{array}{l}\text { Cleaved to } \\
2 \text { - to } 4 \text {-cell } \\
\text { stage }\end{array}$ & Analysable & $\begin{array}{l}\text { Abnormal } \\
\text { karyotype }\end{array}$ & Aneuploid & Mosaic \\
\hline \multicolumn{10}{|l|}{$2 \min \mathrm{RT}$} \\
\hline Experimental & 27 & 18 & $\mathbf{0}$ & - & 18 & 17 & 7 & 4 & 3 \\
\hline Control & 29 & 27 & 0 & - & 27 & 25 & 2 & 2 & 0 \\
\hline \multicolumn{10}{|c|}{$2 \min R T+1$ h at $37^{\circ} \mathrm{C}$} \\
\hline Experimental & 27 & 27 & 1 & 1 & 26 & 25 & 6 & 4 & 2 \\
\hline Control & 26 & 25 & 0 & - & 25 & 22 & 3 & 3 & 0 \\
\hline \multicolumn{10}{|c|}{$2 \min \mathrm{RT}+4 \mathrm{~h}$ at $37^{\circ} \mathrm{C}$} \\
\hline Experimental & 24 & 24 & 0 & - & 24 & 21 & 5 & 4 & 1 \\
\hline Control & 25 & 22 & 1 & 0 & 21 & 20 & 3 & 2 & 1 \\
\hline \multicolumn{10}{|l|}{$10 \mathrm{~min} \mathrm{RT}$} \\
\hline Experimental & 28 & 19 & 2 & 1 & 17 & 17 & 10 & 6 & 4 \\
\hline Control & 24 & 23 & 2 & 0 & 21 & 18 & 2 & 2 & 0 \\
\hline \multicolumn{10}{|c|}{$10 \mathrm{~min} \mathrm{RT}+1 \mathrm{~h}$ at $37^{\circ} \mathrm{C}$} \\
\hline Experimental & 33 & 20 & 2 & 2 & 18 & 18 & 15 & 12 & 3 \\
\hline Control & 29 & 26 & 0 & - & 26 & 24 & 5 & 3 & 2 \\
\hline \multicolumn{10}{|c|}{$10 \mathrm{~min} \mathrm{RT}+4 \mathrm{~h}$ at $37^{\circ} \mathrm{C}$} \\
\hline Experimental & 30 & 20 & 1 & 0 & 19 & 18 & 12 & 7 & 5 \\
\hline Control & 28 & 26 & 0 & - & 26 & 23 & 5 & 3 & 2 \\
\hline \multicolumn{10}{|l|}{$30 \min \mathrm{RT}$} \\
\hline Experimental & 35 & 19 & 9 & 4 & 10 & 7 & 6 & 4 & 2 \\
\hline Control & 31 & 27 & 3 & 0 & 24 & 17 & 3 & 2 & 1 \\
\hline \multicolumn{10}{|c|}{$30 \mathrm{~min} \mathrm{RT}+1 \mathrm{~h}$ at $37^{\circ} \mathrm{C}$} \\
\hline Experimental & 26 & 9 & 4 & 2 & 5 & 5 & 4 & 1 & 3 \\
\hline Control & 22 & 18 & 0 & 0 & 18 & 14 & 2 & 2 & 0 \\
\hline \multicolumn{10}{|c|}{$30 \mathrm{~min} \mathrm{RT}+4 \mathrm{~h}$ at $37^{\circ} \mathrm{C}$} \\
\hline Experimental & 30 & 15 & 7 & 2 & 8 & 7 & 5 & 4 & 1 \\
\hline Control & 28 & 28 & 0 & 0 & 28 & 24 & 4 & 3 & 1 \\
\hline
\end{tabular}

RT, room temperature.

either $1 \mathrm{~h}$ (Fig. $5 b$ ) or $4 \mathrm{~h}$ (Fig. $5 c$ ). However, the incidence of cleavage in activated oocytes that had been cooled for $30 \mathrm{~min}$ and treated with puromycin immediately is significantly lower than both the controls (Fig. 5a) and the oocytes that had been returned to $37^{\circ} \mathrm{C}$ for either $1 \mathrm{~h}$ (Fig. $5 b$ ) or $4 \mathrm{~h}$ (Fig. $5 \mathrm{c}$ ).

\section{Effects of temperature reduction on the chromosome complement of parthenotes}

Analysable spreads were obtained from parthenotes at the 2- to 4-cell stages, with a minimum of two (range 2-4) analysable blastomeres per parthenote. There is no significant difference in the rate of analysable metaphase spreads between any of the control and experimental groups (Table 2).

The incidence of chromosomal abnormality is significantly greater in parthenotes developed from oocytes cooled to RT and activated immediately than in controls, whether oocytes were cooled for $2 \mathrm{~min}$,
$10 \mathrm{~min}$ or $30 \mathrm{~min}$ (Fig. 6a). There is no significant difference in the incidence of chromosomal abnormality between parthenotes derived from oocytes exposed to RT for different lengths of time.

The incidence of chromosomal abnormality is not significantly different in parthenotes derived from oocytes that were exposed to RT for $2 \mathrm{~min}$ and then returned to $37^{\circ} \mathrm{C}$ for either $1 \mathrm{~h}$ (Fig. 6b) or $4 \mathrm{~h}$ (Fig. 6c) compared with controls. In contrast, where oocytes were exposed to RT for $10 \mathrm{~min}$ or $30 \mathrm{~min}$, the incidence of chromosomal abnormality among parthenotes remained significantly higher than in controls, whether they were returned to $37^{\circ} \mathrm{C}$ for $1 \mathrm{~h}$ (Fig. 6b) or $4 \mathrm{~h}$ (Fig. 6c).

There is no significant difference in the rate of chromosomal abnormality among any of the control groups.

Among all the experimental groups, a total of 50 of 63 oocytes analysed displayed spindle abnormality, compared with a total of 23 of 41 parthenotes that 


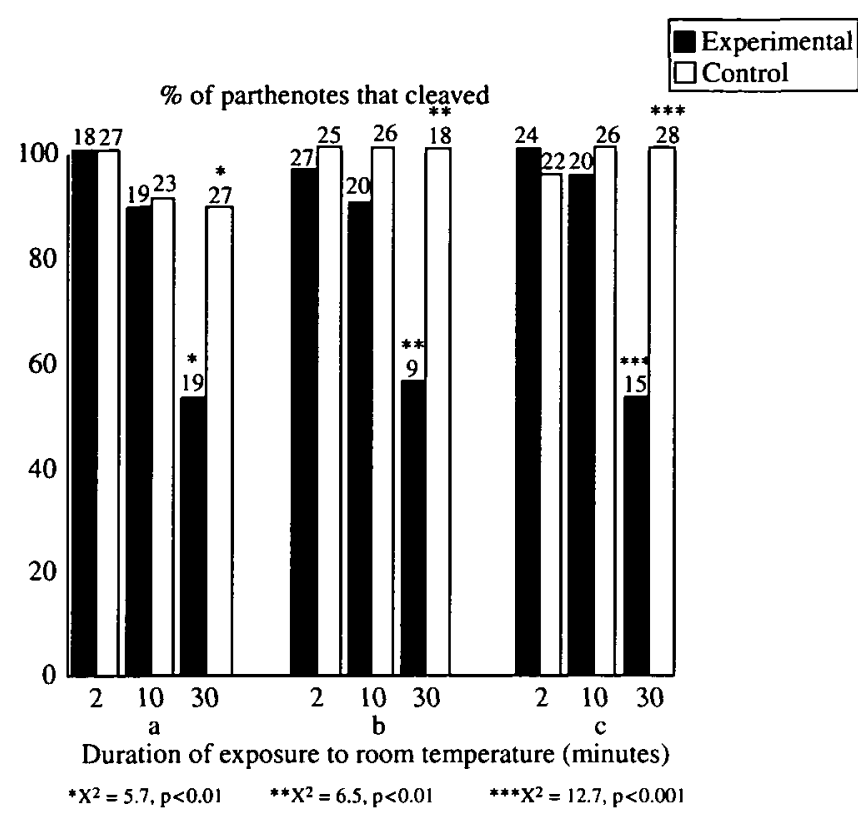

Figure 5 Histogram illustrating the incidence of cleavage in parthenotes developed from oocytes exposed to temperature reduction for 2,10 or $30 \mathrm{~min}$ followed by $(a)$ immediate analysis, or incubation at $37^{\circ} \mathrm{C}$ for $(b) 1 \mathrm{~h}$ or $(c) 4 \mathrm{~h}$.

were chromosomally abnormal. There is a statistically significant association between spindle abnormality in oocytes, and chromosomal abnormality in parthenotes $\chi^{2}=5.41 ; p<0.01$ ).

\section{Discussion}

In the human, the ovulated oocyte is arrested at second meiotic metaphase, with anastral, barrelshaped spindles that are slightly pointed at each pole, and located perpendicular to the oolemma (Pickering et al., 1988). The spindle, to which the chromosomes are attached by kinetochores, is composed of microtubules, which are highly sensitive to temperature changes. Thus, depolymerisation increases at temperatures below $20^{\circ} \mathrm{C}$ and is complete at $0-4^{\circ} \mathrm{C}$, while repolymerisation is favoured by a rise in temperature above $20^{\circ} \mathrm{C}$ (Dustin, 1984). In the mouse, it has been demonstrated that when oocytes are cooled to $25^{\circ} \mathrm{C}$, $18^{\circ} \mathrm{C}$ or $4^{\circ} \mathrm{C}$, progressive disassembly of the meiotic spindle results, with the extent of depolymerisation relating to the duration and degree of the fall in temperature. Similar effects have been observed when human oocytes are cooled slowly at $1{ }^{\circ} \mathrm{C} / \mathrm{min}$ to $0^{\circ} \mathrm{C}$ (Sathananthan et al., 1988). In the mouse, repolymerisation occurs when oocytes are warmed to $37^{\circ} \mathrm{C}$, and apparently normal spindles form once more (Pickering \& Johnson, 1987; Sathananthan et al., 1992), whereas in the human, the effects are irreversible
(Pickering et al., 1990). This differential ability to restore the spindle structure after temperatureinduced damage may be explained by the difference in amounts of pericentriolar material (PCM) present in the oocyte, since the construction of a normal spindle requires both chromosomes to motivate tubulin polymerisation, and PCM to organise it; in the mouse oocyte, PCM is relatively abundant compared with the human (Pickering et al., 1990).

During procedures for assisted conception that expose human oocytes to potential temperatureinduced damage, efforts are usually made to ensure that oocytes are maintained at $37^{\circ} \mathrm{C}$. Despite this, it is likely that during such procedures, which include oocyte retrieval, the transfer of gametes into the Fallopian tubes, and intracytoplasmic sperm injection, some oocytes may be subjected to a fall in temperature. Indeed, depending on the skill of the operator, oocytes may spend over $2 \mathrm{~min}$ on a microscope stage during oocyte retrieval (average per operator ranging from 45 to $185 \mathrm{~s}$; P. Almeida, unpublished observation from this Unit).

While in the earlier study (Pickering et al., 1990), oocytes were transferred directly from drops of medium at $37^{\circ} \mathrm{C}$ to drops at $\mathrm{RT}$; the present study mimics more closely the conditions to which oocytes may be exposed during standard procedures for assisted conception, in that the dishes containing the oocytes were moved from $37^{\circ} \mathrm{C}$ and left at RT for as little as $2 \mathrm{~min}$. Moreover, this study is in agreement

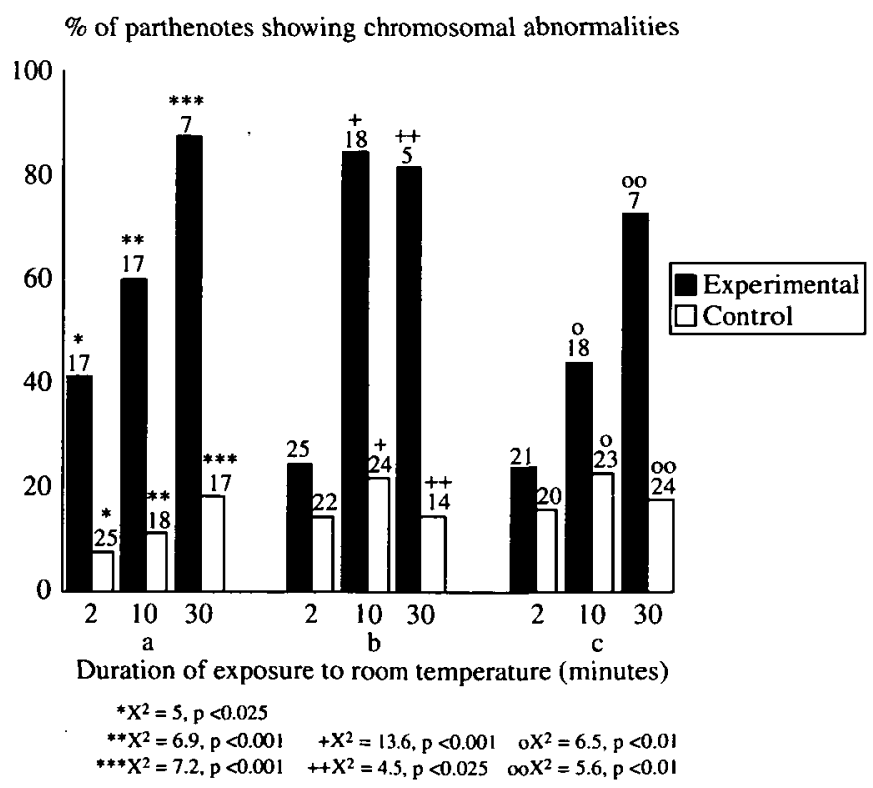

Figure 6 Histogram illustrating the incidence of chromosomal abnormality in parthenotes developed from oocytes exposed to temperature reduction for 2,10 or $30 \mathrm{~min}$ followed by $(a)$ immediate analysis, or incubation at $37^{\circ} \mathrm{C}$ for $(b)$ $1 \mathrm{~h}$ or $(c) 4 \mathrm{~h}$. 
with the earlier study, which found irreversible disruption of the meiotic spindle following transfer from $37^{\circ} \mathrm{C}$ to $\mathrm{RT}$ for $10 \mathrm{~min}$ or $30 \mathrm{~min}$, with evidence of chromosomal dispersal. Our results demonstrate that when oocytes are exposed to RT for $2 \mathrm{~min}$, after which the temperature of the culture drops has decreased to $32^{\circ} \mathrm{C}$, the spindle is disrupted, although this effect is reversible. Thus, while microtubules are extremely sensitive to temperature changes, depolymerisation commences, but is reversible, even with a fall in temperature of only $5^{\circ} \mathrm{C}$.

It has been suggested that any loss of tubulin dimers during cooling could result in dislocation of chromosomes from the metaphase plate, seriously affecting the normal segregation of chromosomes during anaphase, and resulting in aneuploidy and mosaicism (Kola et al., 1988). Although the data presented here indicate temperature-induced spindle anomalies are not directly associated with dispersal of chromosomes from the meiotic metaphase plate, the effect of temperature-induced spindle damage on chromosomal constitution may not arise until after fertilisation and mitosis. This possibility was examined by parthenogenetic activation, and cytogenetic analysis of the parthenotes generated from oocytes exposed to a drop in temperature. The results demonstrate that there is a direct association between temperatureinduced spindle damage and the incidence of chromosomal abnormalities in parthenotes developed from oocytes exposed to RT for different lengths of time $\left(\chi^{2}=5.41 ; p<0.01\right)$. These effects on the spindle and on chromosomal dispersal are reversed if oocytes are exposed for only $2 \mathrm{~min}$, but irreversible if exposed for 10 or $30 \mathrm{~min}$.

In addition to the effects on the spindle and on chromosomal dispersal, the rate of parthenogenetic activation, and of cleavage of resulting parthenotes, are also affected by temperature reduction. Again, these effects are reversed if oocytes are left at RT for only $2 \mathrm{~min}$, but not after $10 \mathrm{~min}$ or $30 \mathrm{~min}$. Thus, the damage induced by temperature reduction is more far-reaching than simply an effect on the microtubules, possibly resulting in alteration of other cytoplasmic proteins such as cytostatic factor (CSF) and maturation promoting factor (MPF), which are involved in regulation of the cell cycle.

Since the oocytes used for these investigations had been cultured in vitro for $20 \mathrm{~h}$ longer than those used by Pickering et al. (1990), it might be argued that the high rate of spindle abnormalities reported here may be merely a manifestation of oocyte ageing in vitro (Pickering et al., 1988), and that this, rather than temperature-induced spindle damage, is responsible for chromosome scattering. However, the inclusion of appropriate controls, all of which showed a significantly lower abnormality rate, for both the spindle and chromosomes, than their respective experimental groups indicates that this is not the case. Indeed, a number of studies have shown that the morphological, biochemical, cytoskeletal and chromosomal integrity of the human oocyte is maintained in culture for up to $72 \mathrm{~h}$ (Ortiz et al., 1982; Gifford et al., 1987; Eichenlaub-Ritter et al., 1988; Tarín et al., 1991).

Astral spindles (Fig. 1c), which represent $3.8 \%$ and $3.7 \%$ of abnormalities in the experimental and control groups respectively in the present study, were not observed by Pickering et al. (1990), who suggested that since human oocytes lack PCM foci, nucleation of microtubular asters did not take place. Possible explanations for this difference include the use of fresh compared with aged oocytes, the relatively small sample analysed in the earlier study, or the different effect of a sudden compared with a gradual exposure to temperature drop.

The clinical implications of the findings of the present study are significant, and provide one explanation for the high incidence of chromosomal abnormalities reported among human preimplantation embryos (Plachot et al., 1988; Ma et al., 1990; Pellestor et al., 1994). Further studies will be necessary to determine the temperature and/or the time of exposure to $\mathrm{RT}$, between $2 \mathrm{~min}$ and $10 \mathrm{~min}$, at which temperatureinduced damage becomes irreversible.

\section{Acknowledgements}

P.A.A. is a holder of the Edmund Davis Scholarship of the University of London. The authors would like to thank Dr Kevin Pedley for his help with confocal microscopy.

\section{References}

Almeida, P.A. \& Bolton, V.N. (1993). Immaturity and chromosomal abnormalities in oocytes that fail to develop pronuclei following insemination in vitro. Hum. Reprod. 8, 229-32.

Bolton, V.N., Hawes, S.M., Taylor, C.T. \& Parsons, J.H. (1989). Development of spare human preimplantation embryos in vitro: an analysis of the correlations among gross morphology, cleavage rates, and development to the blastocyst. J. IVF and ET 6, 30-5.

Dustin, P. (1984). Microtubules, 2nd edn. Berlin: Springer.

Eichenlaub-Ritter, U., Stahl, A. \& Luciani, J.M. (1988). The microtubular cytoskeleton and chromosomes of unfertilised human oocytes aged in vitro. Hum. Genet. 80, 259-64.

Gifford, D.J., Fleetham, J.A., Mahadevan, M.M., Taylor, P.J. \& Schultz, G.A. (1987). Protein synthesis in mature human oocytes. Gamete Res. 18, 97-107.

Kola, I., Kirby, C., Shaw, J., Davey, A. \& Trounson, A. (1988). Vitrification of mouse oocytes results in aneuploid zygotes and malformed fetuses. Teratology 38, 467-74.

Ma, S., Kalousek, D.K., Zouves, C., Yuen, B.H., Gomel, V. \& 
Moon, Y.S. (1990). The chromosomal complements of cleaved human embryos resulting from in vitro fertilisation. J. IVF and ET 7, 16-21.

Maro, B., Howlett, S.K. \& Webb, M. (1985). Non-spindle microtubule organizing centres in metaphase II-arrested mouse oocytes. J. Cell Biol. 101, 1665-72.

Ortiz, M.E., Salvatierra, A.M., Lopel, J., Fernandez, E. \& Croxatto, H.B. (1982). Post-ovulatory ageing of human ova. I. Light microscopic observations. Gamete Res. 6, 11-17.

Pellestor, F., Girardet, A., Andreo, B., Arnal, F. \& Humeau, C. (1994). Relationship between morphology and chromosomal constitution in human preimplantation embryos. Mol. Reprod. Dev. 39, 141-6.

Pickering, S.J. \& Johnson, M.H. (1987). The influence of cooling on the organisation of the meiotic spindle of the mouse oocyte. Hum. Reprod. 2, 207-16.

Pickering, S.J., Johnson, M.H., Braude, P.R. \& Houliston, E. (1988). Cytoskeletal organisation in fresh, aged and spontaneously activated human oocytes. Hum. Reprod. 3, 978-89.

Pickering, S.J., Cant, A., Braude, P.R., Currie, J. \& Johnson, M.H. (1990). Transient cooling to room temperature can cause irreversible disruption of the meiotic spindle in the human oocyte. Fertil. Steril. 54, 102-8.

Plachot, M., Veiga, A., Montagut, J., de Grouchy, J., Calderon, G., Lepretre, S., Junca, A.M., Santalo, J., Carles, E., Mandelbaum, J., Barri, P., Degoy, J., Cohen, J., Egozcue, J., Sabatier, J.C. \& Salat-Baroux, J. (1988). Are clinical and biological IVF parameters correlated with chromosomal disorders in early life: a multicentric study. Hum. Reprod. 3, 627-35.

Sathananthan, A.H., Trounson, A., Freeman, L. \& Brady, T. (1988). The effects of cooling human oocytes. Hum. Reprod. 3, 968-77.

Sathananthan, A.H., Kirby, C., Peura, A. \& Trounson, A. (1992). Mouse oocyte cooling. J. Assist. Reprod. Genet. 9, $139-48$.

Tarín, J.J., Gómez, E. \& Pellicer, A. (1991). Chromosome anomalies in human oocytes in vitro. Fertil. Steril. 55, 964-9.

Waterstone, J.J. \& Parsons, J.H. (1992). A prospective study to investigate the value of flushing follicles during transvaginal ultrasound-directed follicle aspiration. Fertil. Steril. 57, 221-3. 